\title{
PENGUATAN KPK (KETAHANAN PANGAN KELUARGA) PADA MASA PANDEMI DI DESA SALAMKANCI
}

\author{
Megita Dwi Pamungkas*1, Rina Rahayu², Fadhila Rahmawati ${ }^{3}$ \\ 1,2,3 Universitas Tidar \\ *e-mail: megitadwip@untidar.ac.id¹, rinarahayu@untidar.ac.id2,fadhilahrahmawati@untidar.ac.id³
}

\begin{abstract}
Abstrak
Tujuan kegiatan ini adalah mengatasi permasalahan yang dihadapi mitra yaitu kurangnya kesadaran masyarakat untuk memanfaatkan lahan pekarangan guna memenuhi kebutuhan pangan keluarga di masa pandemi. Metode yang digunakan dalam kegiatan ini adalah PRA (Parcitipatory Rural Appraisal). Pendekatan ini melibatkan masyarakat untuk memahami masalah dan meningkatkan partisipasi masyarakt untuk menyelesaikan masalah mereka sendiri. Peserta kegiatan ini adalah ibu-ibu anggota PKK di Desa Salamkanci, Kecamatan Bandongan, Kabupaten Magelang. Kegiatan pertama yaitu sosialisasi yang dilanjutkan penyuluhan tentang ketahanan pangan keluarga (KPK) dan strategi penguatan KPK, kemudian diberi motivasi dan pelatihan tentang pemanfaatan lahan pekarangan selanjutnya warga diberikan bibit-bibit tanaman hortikultura yang diambil dari kebun bibit untuk mempraktekkan hasil pelatihan di pekarangan masing-masing. Hasilnya kesadaran masyarakat untuk memanfaatkan lahan pekarangan untuk menanam berbagai jenis tanaman meningkat.
\end{abstract}

Kata kunci: Ketahanan Pangan Keluarga, Pandemi

\section{PENDAHULUAN}

Desa Salamkanci adalah salah satu pedesaan di Kecamatan Bandongan. Berjarak 9 km dari Universitas Tidar, Desa Salamkanci termasuk desa berhawa sejuk di Magelang. Sebagian besar wilayahnya adalah lahan sawah yang bisa panen padi tiga kali dalam setahun. Sepanjang tahun, warga desa Salamkanci hanya menanam jenis tanaman padi di sawahnya. Sehingga, untuk kebutuhan pangan yang lain, seperti sayur, bumbu masak, dan buah, mereka harus membeli di pasar terdekat. Padahal, sebenarnya warga desa bisa memanfaatkan lahan pekarangan yang ada di sekitar mereka untuk menanam jenis tanaman sayur, bumbu masak, maupun buah-buahan.

Keterbatasan pemanfataan lahan pekarangan juga menjadi alasan masyarakat untuk tidak menanam tanaman pangan di sekitar rumah. Hal serupa kami lihat ketika melakukan survei awal ke lokasi mitra kegiatan ini yaitu Desa Salamkanci. 

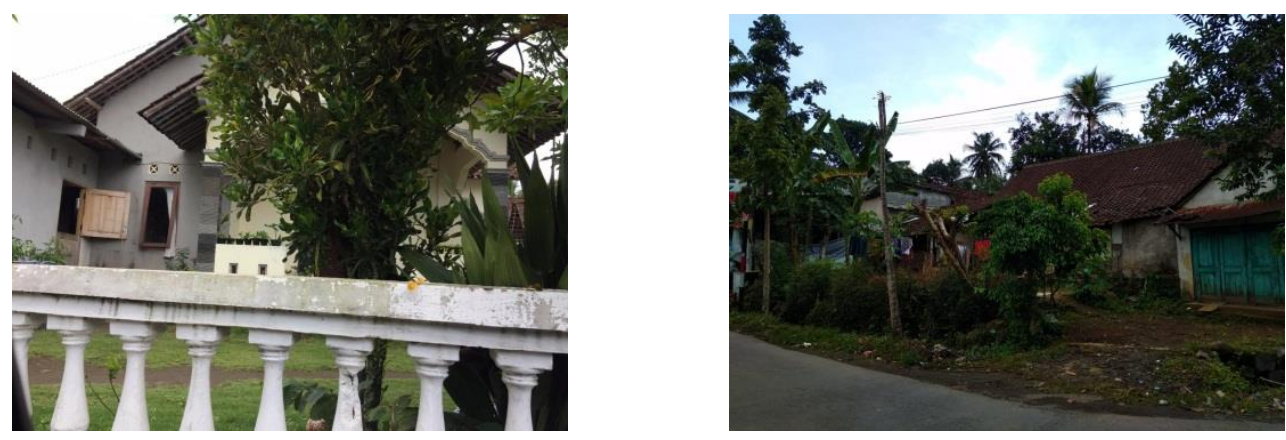

Gambar 1. Kondisi Lahan Pekarangan Warga Desa Salamkanci

Permasalahan yang lain adalah ketidaktahuan mereka tentang budidaya tanaman hortikultura. Hortikultura adalah ilmu yang mempelajari budidaya tanaman dilingkungan pekarangan yang terbatas seperti tanaman buah, sayur dan tanaman hias (Puryati, Kuntadi, \& Basuki: 2018).

Kebutuhan pangan keluarga tidak bisa diabaikan dalam kehidupan sehari-hari terutama di masa pandemi. Fokus kebutuhan pangan tidak hanya pada tingkat wilayah akan tetapi juga pada tingkat keluarga dan individu (Saraswati: 2019). Selain bahan makanan pokok yaitu nasi yang dihasilkan dari padi, ada berbagai jenis bahan kebutuhan yang sebenarnya bisa dipenuhi sendiri oleh keluarga seperti sayuran, buah dan TOGA.

Pemahaman mengenai ketahanan dan kerentanan pangan dan gizi tercantum dalam kerangka Konsep Ketahanan Pangan dan Gizi. Di Indonesia, Undang-undang No. 7 tahun 1996 tentang Pangan mengartikan Ketahanan Pangan sebagai kondisi terpenuhinya pangan bagi rumah tangga yang tercermin dari tersedianya pangan yang cukup, baik jumlah maupun mutunya, aman, merata dan terjangkau.

Saat ini, dunia sedang menghadapi Pandemi Covid-19 tak terkecuali di Indonesia. Presiden Joko Widodo meminta seluruh lapisan masyarakat untuk merapkan pola adaptasi baru di tengah pandemi untuk memutus rantai penyebaran virus Corona. Dengan diberlakukan adaptasi baru atau new normal ini masyarakat dituntut tetap produktif, sala satunya adalah dengan menanam sayuran, buah, dan tanaman obat di lahan pekarangan rumah. Hal ini sebagai upaya untuk memenuhi kebutuhan pangan keluarga di era pandemi covid-19.

Mulyo, Sugiyarto, \& Widada, (2015) menyatakan bahwa ketahanan dan kemandirian pangan bagi suatu rumah tangga dipengaruhi oleh kemampuan rumah tangga tersebut dalam memenuhi kebutuhan pangan keluarga. Jika kebutuhan pangan ini dapat dipenuhi ditingkat keluarga maka dapat menghemat keuangan keluarga sehingga diharapkan mampu mengurangi pengeluaran sehingga lambat laun akan meningkatkan kesejahteraan keluarga. 
Masalah yang sering dihadapi oleh masyarakat, utamanya adalah ibu rumah tangga adalah kurangnya kesadaran untuk memanfaatkan lahan pekarangan yang terbatas. Padahal, Dapat dikatakan wanita atau ibu rumah tangga mempunyai peran penting dalam upaya meningkatkan ketahanan pangan keluarga (Yuniriyanti, Sudarwati, dan Nurdewanto: 2019).

Dengan kondisi tanah Desa Salamkanci sangat subur sehingga tanaman mudah hidup dan tumbuh subur jika ditanam dengan media tanah akan membantu mempermudah terwujudnya usaha peningkatan ketahanan pangan keluarga yaitu dengan menanam sendiri berbagai jenis tanaman yang merupakan kebutuhan pangan sehari-hari. Dengan terpenuhinya kebutuhan pangan sehari-hari maka pengeluaran akan berkurang dan akan meningkatkan kesejahteraan masyarakat.

\section{METODE}

Metode kegiatan ini berupa sosialisasi, penyuluhan dan pelatihan kepada ibu-ibu anggota PKK Desa Salamkanci, Kecamatan Bandongan, Kabupaten Magelang. Setelah diberikan pelatihan, selanjutnya peserta diberi bibit-bibit tanaman holtikultura yang diambil dari kebun bibit yang ada di Desa Salamkanci untuk ditanam di lahan pekarangan masing-masing dengan pendampingan tim pelaksana. Adapun untuk rincian kegiatannya adala sebagai berikut.

\section{Tahapan Persiapan}

Tahap persiapan yang dilakukan meliputi:

a) Survei

b) Pemantapan dan penentuan lokasi dan sasaran

c) Penyusunan bahan/materi sosialisasi, penyuluhan dan pelatihan

\section{Tahap Pelaksanaan Pelatihan}

Tahap pelaksanaan dilakukan setelah seluruh tahap persiapan selesai. Dalam tahap ini yang dilakukan adalah sebagai berikut:

a) Sosialisasi tentang keberadaan kebun bibit yang ada dan fungsi kebun bibit serta manfaat kebun bibit tersebut.

b) Penyuluhan tentang ketahanan pangan keluarga (KPK) dan strategi untuk penguatan KPK.

c) Motivasi dan pelatihan budidaya tanaman holtikultura

d) Pemberian bibit kepada peserta 
Untuk melaksanakan kegiatan tersebut digunakan beberapa metode pelatihan, yaitu:

a) Metode Ceramah

Metode ceramah dipilih untuk mensosialisasikan tentang kebun bibit dan memberikan penjelasan tentang pengertian ketahanan pangan keluarga serta bagaimana strategi penguatannya.

b) Metode Tanya Jawab

Metode tanya jawab dipilih untuk penyampaian materi ketahanan pangan keluarga dan strategi penguatannya.

c) Metode Simulasi

Metode simulasi ini sangat penting diberikan kepada para peserta pelatihan untuk memberikan kesempatan mempraktikkan materi pelatihan budidaya tanaman holtikultura.

\section{Tahap Evaluasi}

Keberhasilan kegiatan pengabdian masyarakat ini akan dievaluasi dengan mengamati hasil pemanfaatan lahan pekarangaan warga. Selain itu pengabdian masyarakat ini juga akan dinilai dengan instrument kriteria penilaian tingkat kebermanfaatan kegiatan pelatihan ini oleh peserta pelatihan.

\section{HASIL DAN PEMBAHASAN}

Kegiatan Penguatan KPK (Ketahanan Pangan Keluarga) Pada Masa Pandemi Di Desa Salamkanci merupakan salah satu Program Kemitraan Masyarakat yang dilaksanakan Dosen di lingkungan Universitas Tidar. Kegiatan ini dilaksanakan selama kurang lebih 6 bulan yang dimulai dari kegiatan survei awal sampai terakhir adalah melakukan evaluasi kebermanfaatan yang dilaksanakan di Desa Salamkanci. Kegiatan inti dari Program Kemitraan Masyarakat ini adalah 1) sosialisasi tentang keberadaan kebun bibit yang ada dan fungsi kebun bibit serta manfaat kebun bibit tersebut; 2) penyuluhan tentang ketahanan pangan keluarga (KPK) dan strategi untuk penguatan KPK; 3) motivasi dan pelatihan budidaya tanaman holtikultura, dan 4) pemberian bibit kepada peserta.

Sebelum melaksanakan kegiatan, tim pengabdian menyusun bahan/materi sosialisasi, penyuluhan dan pelatihan di sekitar bulan Juli - Agustus 2021. Rincian agenda dalam kegiatan tersebut adalah sebagai berikut. Pada hari pertama, 26 Agustus 2021 tim melakukan sosialisasi tentang kegiatan PKM, Sosialisasi dilaksanakan di Rumah Ketua RT 03 RW 01 Dukuh Salam Desa Salamkanci yang di hadiri oleh para lbu-ibu PKK dan remaja RT 03 RW 
01 Dukuh Salam Desa Salamkanci. Para lbu-ibu dan remaja sangat antusias ketika pelaksanaan kegiatan sosialisasi berlangsung. Pada hari pertama, Bapak Megita Dwi Pamungkas, M.Pd. selaku pemateri membuka kegiatan ini dan memberikan informasi kepada Bapak/lbu Guru bahwa program ini merupakan salah satu program kemitraan masyarakat untuk menjalankan salah satu Tridarma Perguruan Tinggi yaitu pengabdian kepada masyarakat yang salah satunya adalah memberikan pelatihan tentang Penguatan KPK (Ketahanan Pangan Keluarga) Pada Masa Pandemi Di Desa Salamkanci dengan harapan pengalaman dari kegiatan yang akan dilakukan ini dapat meningkatkan ketahanan pangan keluarga yaitu dengan menanam sendiri berbagai jenis tanaman yang merupakan kebutuhan pangan sehari-hari.

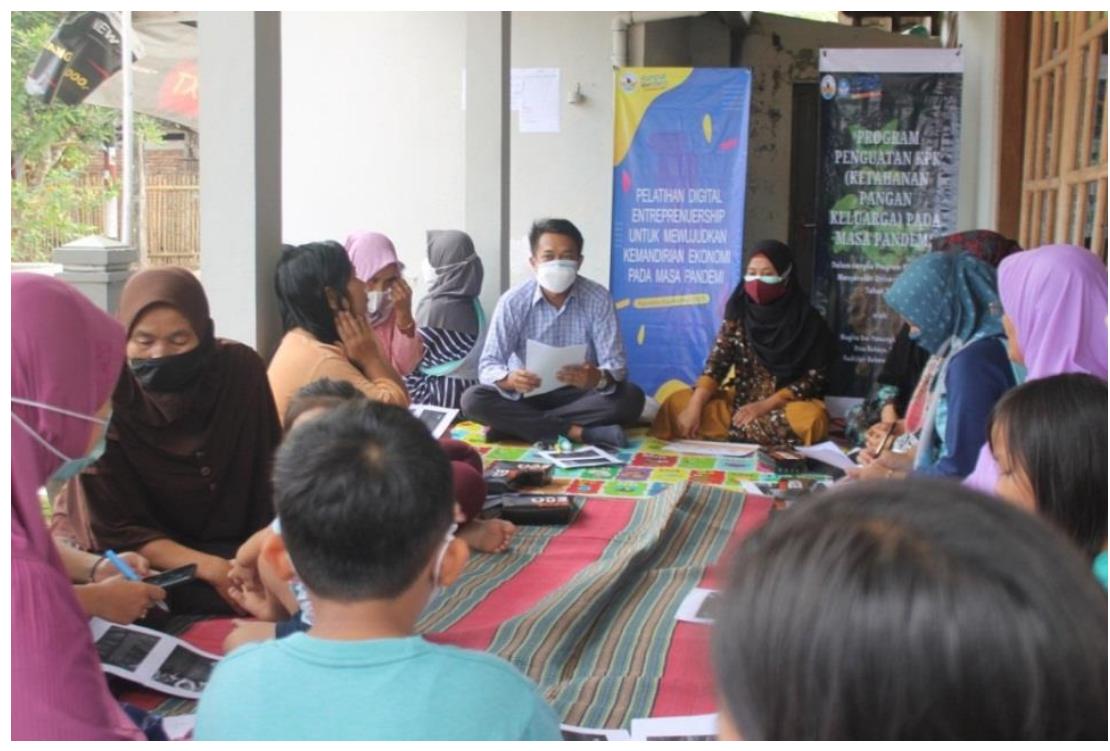

Gambar 2. Pelaksanaan Kegiatan Sosialisasi

Pada hari kedua, Minggu, 29 Agustus 2021 kegiatan dilanjutkan dengan kegiatan penyuluhan tentang ketahanan pangan keluarga (KPK) dan strategi untuk penguatan KPK. Pada materi tersebut dibahas tentang pangan, ketahanan pangan, dan bagaimana ketahanan pangan pada masa pandemi. Kebutuhan pangan keluarga tidak bisa diabaikan dalam kehidupan sehari-hari terutama di masa pandemi. Selain bahan makanan pokok yaitu nasi yang dihasilkan dari padi, ada berbagai jenis bahan kebutuhan yang sebenarnya bisa dipenuhi sendiri oleh keluarga seperti sayuran, buah dan TOGA. Kegiatan berlangsung dengan baik, para peserta mengikuti kegiatan dengan seksama. 


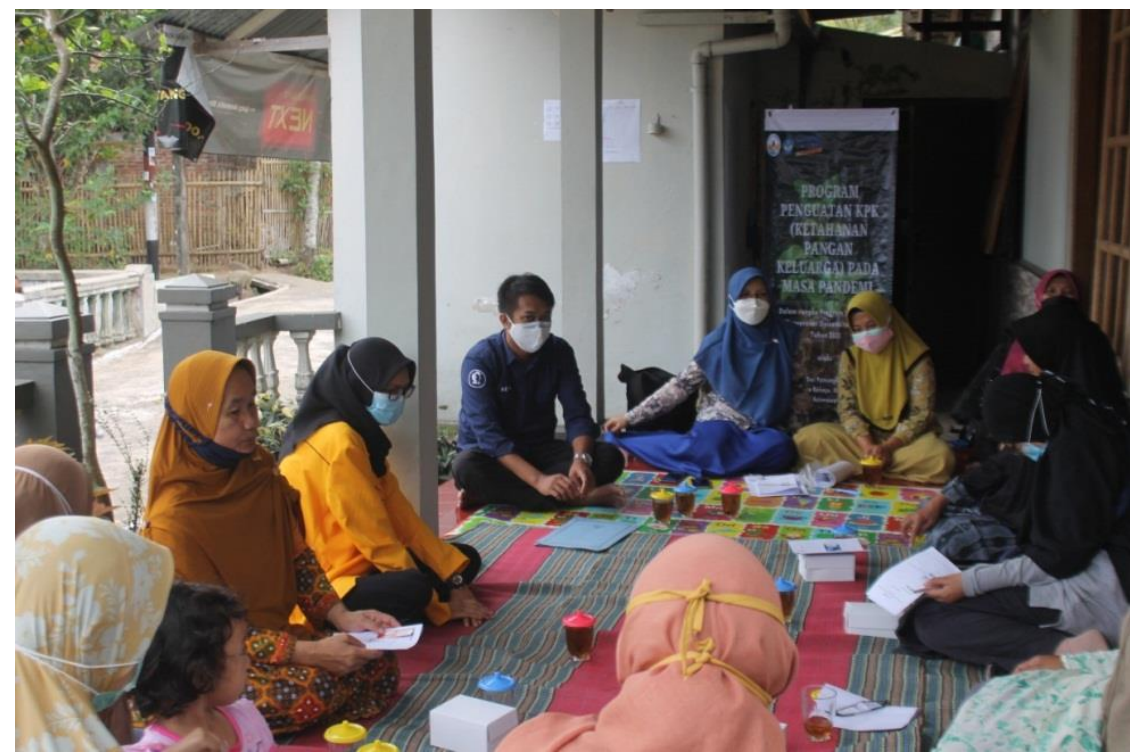

Gambar 3 Pelaksanaan kegiatan Penyuluhan

Kemudian, pada hari ketiga, Minggu, 05 September 2021 kegiatan dilanjutkan dengan pemberian bibit tanaman sayuran dan buah-buahan kepada peserta yang selanjutnya adalah mempraktekkan menanam bersama secara simbolis. Penanaman kemudian secara berkelanjutan dilakukan di pekarangan masing-masing.

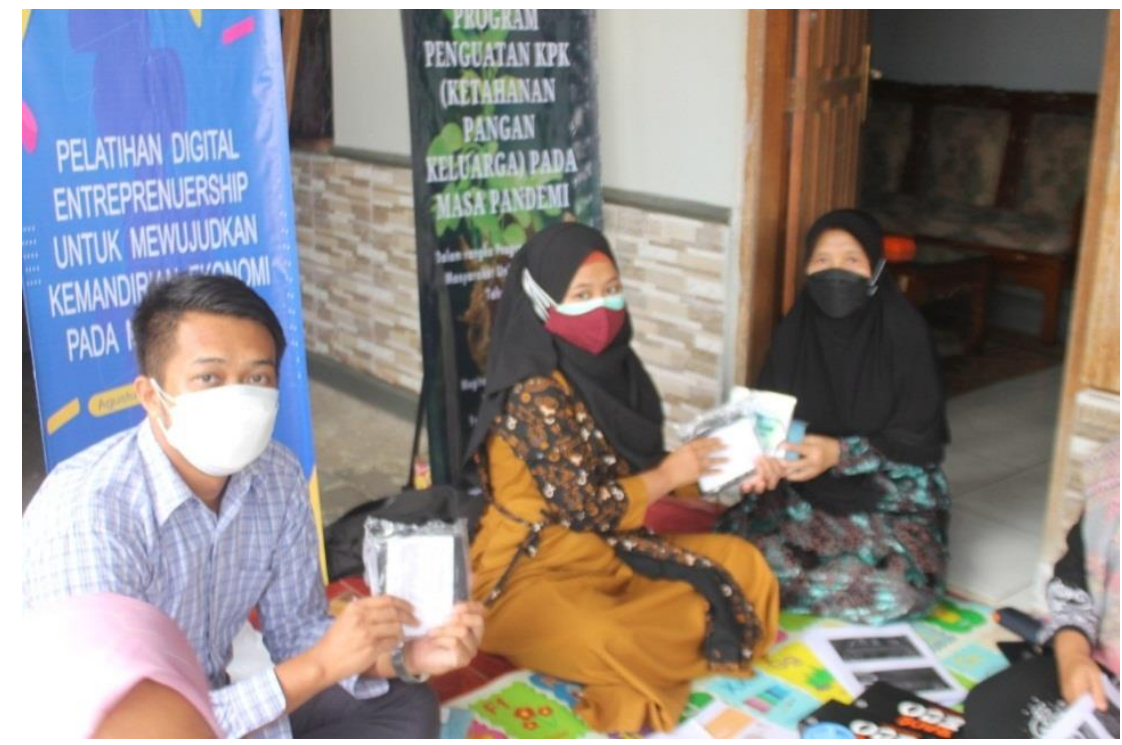

Gambar 4. Pelaksanaan kegiatan hari Ketiga dengan pemberian bibit 
Pada hari berikutnya, kegiatan dilanjutkan dengan memonitoring dan mengevaluasi kebermanfaatan dari penanaman bibit yang telah dilakukan masing-masing peserta. Tim pengabdian bersama peserta melihat tanaman yang sudah tumbuh di salah satu lahan pekarangan.

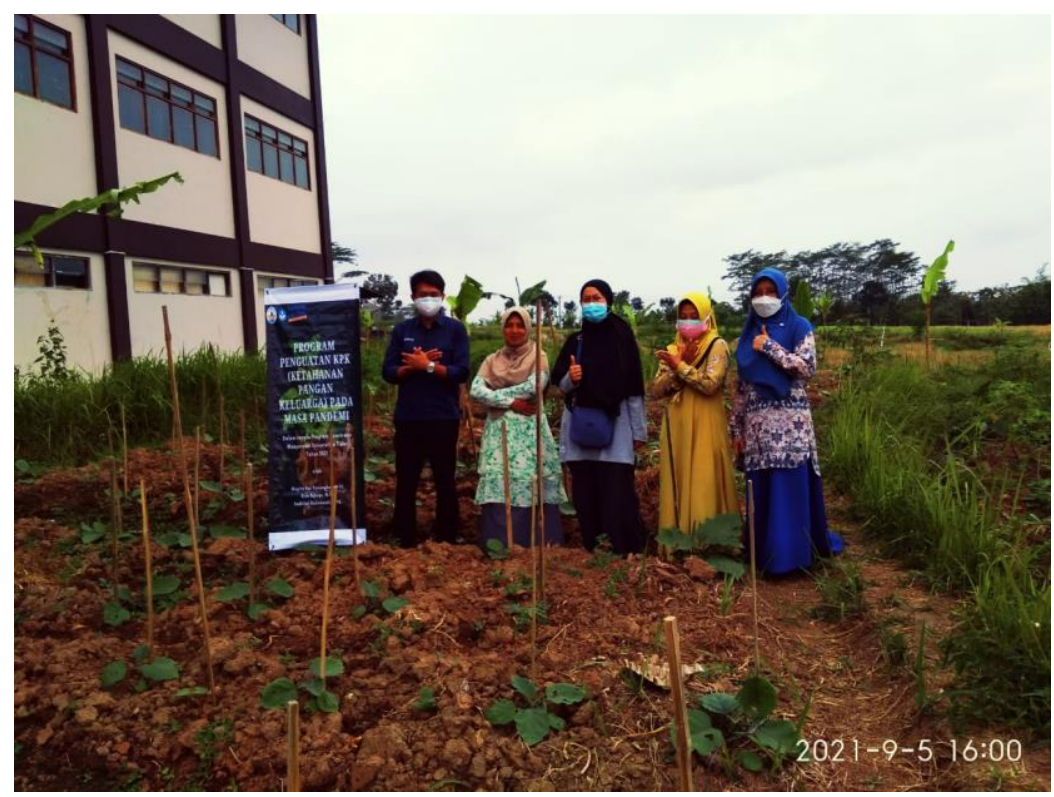

Gambar 5. Pelaksanaan kegiatan evaluasi

\section{KESIMPULAN}

Kegiatan Program Kemitraan Masyarakat ini dilaksanakan dengan memberikan penyuluhan dan pelatihan kepada lbu-ibu anggota PKK tentang ketahanan pangan keluarga (KPK) dan strategi penguatan KPK, kemudian peserta diberikan motivasi melalui beberapa video tentang keberhasilan kegiatan ini di wilayah lain kemudian peserta mengikuti pelatihan budidaya tanaman holtikultura diakhiri dengan pemberian bibit agar peserta dapat mengimplementasikan hasil pelatihan. Hasilnya adalah warga memahami dan memiliki kesadaran maupun ketrampilan tentang ketahanan pangan keluarga dan budidaya holtikultura di lahan pekarangan pada masa pandemi. Berdasarkan temuan data-data pengabdian, dosendosen maupun guru dappihak yang berkepentingan agar melakukan inovasi kegiatan pelatihan yang lain untuk menghadapi masa pendemi yang belum berakhir. 


\section{UCAPAN TERIMA KASIH}

Penulis mengucapkan terima kasih kepada Lembaga Penelitian, Pengabdian Masyarakat, dan Penjaminan Mutu Pendidikan Univeristas Tidar yang telah memberi dukungan financial terhadap pengabdian ini.

\section{DAFTAR PUSTAKA}

Mulyo, J. H., Sugiyarto, S., \& Widada, A. W. (2015). Ketahanan Dan Kemandirian Pangan Rumah Tangga Tani Daerah Marginal Di Kabupaten Bojonegoro. Agro Ekonomi, 26(2), 121-128

Puryati, D., Kuntadi, S., \& Basuki, T.I. (2018). Manajemen Usaha Budidaya Tanaman Hortikultura Dalam Polybag (Tanaman Holtikultura Modern). Jurnal Dharma Bhakti Ekuitas. Vol 3 no 1 September 2018. ISSN 2528-2190

Republik Indonesia. (1996). Undang-Undang No. 7 Tahun 1996 tentang Pangan. Lembaran Negara RI Tahun, (3656)

Saraswati, E. E. (2019). Pengorganisasian masyarakat dalam meningkatkan ketahanan pangan melalui pertanian Hortikutura ramah lingkungan di Dusun Balongkore Desa Ngadirejo Kecamatan Wonoasri Kabupaten Madiun (Doctoral dissertation, UIN Sunan Ampel Surabaya)

Yuniriyantl, E., Nurdewanto, B., \& Sudarwati, R. (2019, September). Pemberdayaan Perempuan Desa Berbasis Kearifan Lokal Dalam Upaya Pencapaian Ketahanan Pangan Keluarga. In Seminar Nasional Sistem Informasi (SENASIF) (Vol. 3, No. 1, pp. 1708-1719) 